points out some of the considerations that lead to commercial success. A good natural water supply is essential as a supply from the town services can never be counted on. The ideal site should be in the vicinity of a wood and on the northern side of a hill as this makes the formation of ice less expensive. It is also advisable, as at Berne, to combine with the ice rink a bathing establishment for summer use. In Zurich the ice rink is combined with a swimming bath which serves in winter as the water tank for the ice rink. Concrete, iron, copper, cork and bitumen are used in the construction of the freezing plate. As their thermal coefficients of expansion are all different and the temperature fluctuations are large the problem presented difficulties. Owing to the thermal expansion, countless minute cracks appear on the plate and this luckily allows it to 'breathe' without injuring the network of tubes. The production of artificial waves in a bathing pool has been studied for many months in the hydraulic laboratory of Messrs. Escher Wyss. They now produce special plant called the 'undosa' for the economic production of artificial waves. Neuchatel has an open air skating rink, and it appears that it is only lack of capital which prevents other Swiss towns from carrying out similar schemes.

\section{The Science Museum}

IN its annual reports to the Board of Education, the Advisory Council of the Science Museum, while giving a general review of the progress of the Museum as a whole, has usually devoted special consideration to one of the divisions, directing attention to the gaps in its collections and indicating how the collections should be developed. In its report for 1933, the Council has therefore dealt with the important sections Water and Air Transport, and its remarks go to show that unless steps are taken there is likely to be wasteful rivalry between the Science Museum and other museums supported by the State. Some of the aeronautical exhibits, the report says are on loan from the Imperial War Museum and others from the Air Ministry. When the War Museum moves to its new quarters at Bethlem it may wish to withdraw its exhibits, while the Air Ministry is contemplating setting up a museum of its own. "This would inevitably create three exhibitions of aviation, each incomplete, and in competition with one another." The creation of the War Museum has already had an unfortunate effect on the Water Transport Collections, for as a result of its inauguration "practically no models of men-of-war of the period between 1914 and 1920 are available, and consequently the collection in the Science Museum is completely truncated. It is regrettable," the report says, "that in this, as in other cases, national collections of the same subject matter should be split up between different Museums, and thus lose much of their educative value to the public." Another rival of the Science Museum, not referred to in the report, may well be the National Maritime Museum, which must almost inevitably encroach on some of the territory already occupied by the Science Museum.

\section{History of Self-Starters for Motor-Cars}

THE Smithsonian Institution has received from the V. G. Apple Laboratories, Ine., of Dayton, Ohio, a valuable collection of early automotive electrical equipment. The founder of the firm, the late Vincent G. Apple, was one of the pioneers who improved motor-car ignition and lighting systems, and one of the first to produce a successful electric starter. This starter, which was very cumbersome, was listed in 1912 at 350 dollars. To-day, when practically every car has a self-starter, the advertising leaflets are amusing. "Every successful device for the public amusement passes through a period of such enormous popularity that the public overlooks its many imperfected details in the desire to be among the first to possess it." It is pointed out that the necessity of cranking the engine of a motor-car is a most exasperating drawback. Compressed air, gas, acetylene gas and spring starters have all been tried and, except when everything is favourable, they have been found untrustworthy. A starter is a convenience when a car is leaving the garage; it is a necessity when it stops at a busy street corner, but what about starting the car when it stops on a level crossing ? The progress of perfecting these devices during the last few years has been so rapid that there is a danger of the beginning and intermediate steps being forgotten. The Smithsonian, therefore, is gathering a collection, as complete as possible, of lighting, starting and ignition equipment.

\section{The American Institute of Electrical Engineers}

IN commemoration of the fiftieth anniversary of its foundation, on May 13, 1884, the American Institute of Electrical Engineers has issued a very interesting memorial number of Electrical Engineering, representing the official monthly journal and transactions. This number, published in May, and containing more than two hundred pages, is dedicated "To the lasting memory of those public spirited leaders who founded and built to its present eminence the American Institute of Electrical Engineers, and to the inspiration of those of the present and future generations who will continue the constructive leadership of this agency for professional development". Among the famous names of contributors to this issue are those of A. E. Kennelly, who writes on "The Work of the Institute in Standardization", C. A. Adams on "Some Major Events in the Life of the Institute", E. W. Rice, Jr., on "A Century of Progress in 50 Years", M. I. Pupin on "The Equation of Electrical Propagation", while Elihu Thomson and D. C. Jackson deal respectively with "Some High Lights of Electrical History" and "The Evolution of Electrical Engineering".

THEse articles are most useful accounts of progress, and provide an illuminating perspective of the manner in which the electrical engineering industry has attained its present status through the continued effort of the comparatively few, of whom the foregoing names are representative. The biographical notices are no 1ess than 92 in number; England 
being well represented by the names of Heaviside, Kelvin, Preece and S. P. Thompson, all of whom were honorary members of the American Institute. The publication is a very fitting tribute to the pioneers whose work is so admirably appraised by C. F. Scott, a former president of the Institute, in the following words: "In the fabric of electrical engineering the long scientific threads of the warp are bound together and given pattern and utility by cross threads which are the life achievements of individuals. As the loom keeps weaving through the years new threads of scientific knowledge are added to the old, and new workers contributing woof of finer quality enrich the beauty and enhance the utility of the product."

\section{Drought of 1934 in the United States}

"BY the close of May 1934 the most extensive drought in the climatological history of the United States had developed in the central valleys, the Lake Region and the North-western and Western States," states J. B. Kincer, Chief of the Climate and Crop Weather Division of the U.S. Weather Bureau, in the Scientific Monthly of July, p. 95. In North Dakota the three spring months (March-May) yielded only $1.25 \mathrm{in}$. of rain, against the previous low record of $2 \cdot 15 \mathrm{in}$. in 1901 . In the north-west the serious shortage in sub-soil moisture and surface water supplies is the result of an accumulated deficiency covering several years. There is no reason to suppose, however, that this prolonged deficiency indicates a permanent drift towards desert-like conditions; for long-period records show that periods of excessive drought may be expected to occur at intervals of $30-40$ years. Thus similar periods of years with markedly deficient rainfall covered the ten years ending with 1864 and again the ten years ending with 1894, while between these periods were successive years with comparatively abundant rains. The 1934 drought was unusual in developing early, and as a consequence, instead of the corn crops being most seriously affected as occurs in summer droughts, the crops which have suffered most so far are hay, pastures and small grains.

\section{Meteorology in Southern Rhodesia}

According to the meteorological report of the Department of Agriculture, Southern Rhodesia, for the year ended June 30, 1933, there was comparatively little change, up to October 1, 1933, in the number of observing stations representing that country, thirty-six new stations having been opened and twenty former stations altered or closed, the total number on that date standing at 601 , of which all but fifty are rainfall stations. The seasonal rainfall was below the normal, as was that of the three preceding seasons with the exception of 1931-32, the deficit being nearly 4 inches. For the fourth year in succession, the seasonal rainfall was forecast with the aid of a formula based on the values of meteorological data at distant 'centres of action', and the sign of the departure from the average was successfully predicted again as at the three earlier attempts-a very praiseworthy result. The report in its general lines follows those of the earlier years. Monthly means of barometric pressure, of temperature and of relative humidity for each of the twenty-four hours are given for Salisbury and Bulawayo, and monthly sunshine totals for the day light hours ; the distribution of rainfall for the whole period is shown cartographically in colours, and there are many climatic summaries on standard lines. There are also summaries of the upper winds measured with the aid of pilot balloons, and of the records of pressure tube anemometers situated at Salisbury and Bulawayo. Dines pressure-tube anemometers have been erected during the year at Fort Victoria, Que Que and Miami. Very satisfactory progress in the collection of comparable climatic data for this country is revealed by this well-arranged and clearly printed report.

\section{The Periodic Law}

THE Mendeleefi Centenary Lecture was delivered before the Chemical Society at the Royal Institution on April 19 by Lord Rutherford, and is printed in the Journal of the Society for May. Lord Rutherford gave an account of the researches on atomic structure which have led to a realisation of the true meaning of the Periodic Law (see Nature, 133, 161, 656; 1934), with so many of which he has himself been associated. He dealt with the question of the order of the elements, as defined by the atomic number, with the discovery of isotopes, with the arrangement of electrons outside the atom, and with a number of related topics. The lecture sets out very clearly the course of investigation which has provided an explanation of the remarkable generalisation proposed by Mendeleeff in 1869 , and also the elucidation of some points of difficulty associated with the Periodic Table before the work of Moseley in 1912-13, which Lord Rutherford described as "an outstanding landmark in the history of our knowledge of the elements".

\section{The Zoological Park of Paris}

MANY initial difficulties having been overcome, Paris has now a zoological park worthy of the nation, constructed in the Bois de Vincennes upon ground reserved by a law of 1860 . The Parc zoologique du Bois de Vincennes, recently inaugurated by the President of the Republic, covers a triangle of about 14 hectares, the longest side bordering Lake Daumesnil. At one of the main entrances rises a hill 68 metres high, on top of which a group of picturesque rocks ingeniously masks two great reservoirs containing the water necessary for the animals. The general idea has been to avoid the stilted cramped zoological garden of the past and to exhibit the animals in open and appropriate spaces, as if in a state of semi-liberty. The photographs illustrating Jean de la Cerisaie's article in La Nature of July 1, p. 30, show that the idea has been carried out with skill and artistry. The Zoological Park of Vincennes with its 1,500 animal inmates takes its place worthily with the other modern zoos of Europe. 